YEARBOOK

of ANTITRUST

and REGULATORY

STUDIES

www.yars.wz.uw.edu.pl
Peer-reviewed scientific periodical, focusing on legal and economic issues of antitrust and regulation. Creative Commons Attribution-No Derivative Works 3.0 Poland License.

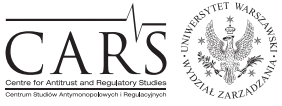

Centre for Antitrust and Regulatory Studies, University of Warsaw, Faculty of Management www.cars.wZ.uw.edu.pl

\title{
The Scope of the Implementation of the Damages Directive in CEE States
}

by

Michal Petr*

\section{CONTENTS}

I. Introduction

II. Private enforcement of competition law

1. The notion of private enforcement

2. The notion of competition law

III. The Damages Directive

IV. National legislation

1. Introductory remarks

2. The 'EU dimension'

3. The 'competition law'

4. The 'private enforcement'

V. The notion of an undertaking

VI. Conclusions

\section{Abstract}

The Damages Directive has a rather limited scope, focusing only on damages claims stemming from anticompetitive agreements or abuse of a dominant position, provided such conduct was able to affect trade between EU Member States. However, Member States are not limited by this scope and so they may decide, when implementing the Directive, to enhance not only claims for damages, but the overall private enforcement of competition law. In this article, we shall explore the

* Senior researcher at Palacky University in Olomouc, Faculty of Law, Czech Republic; e-mail: michal.petr@upol.cz; this article was drafted with support of a project the grant provided by the Palacky University in Olomouc 'Prosazování soutě̌ního práva v České republice' [Enforcement of Competition Law in the Czech Republic], grant No. IGA_PF_2017_009. Article received: 12.07.2017; accepted: 14.08.2017. 
scope of the implementing legislation of selected Central and Eastern European Countries, namely in Bulgaria, Croatia, the Czech Republic, Estonia, Hungary, Latvia, Lithuania, Poland, Romania, Slovakia and Slovenia.

\section{Résumé}

La Directive Dommages a un champ d'application plutôt limité qui se concentre uniquement sur les actions en dommages causés par des accords anticoncurrentiels ou des abus de position dominante, susceptibles d'affecter le commerce entre États membres. Toutefois, les États membres ne sont pas limités par ce champ d'application et peuvent donc décider, lors de la mise en œuvre de la Directive, de renforcer non seulement les actions en dommages, mais aussi l'ensemble de l'application privée du droit de la concurrence. Dans cet article, nous explorerons le champ d'application de la législation de mise en œuvre dans les certains pays d'Europe centrale et orientale, à savoir la Bulgarie, la Croatie, la République tchèque, l'Estonie, la Hongrie, la Lettonie, la Lituanie, la Pologne, la Roumanie, la Slovaquie et la Slovénie.

Key words: competition law; Damages Directive; private antitrust enforcement; undertaking.

JEL: K21

\section{Introduction}

In its landmark Courage judgment of $2001,{ }^{1}$ the Court of Justice of the European Union (hereinafter referred to as 'CJEU') declared that 'a party to a contract liable to restrict or distort competition within the meaning of [Article $101 \mathrm{TFEU}$ ] can rely on the breach of that article to obtain relief from the other contracting party'; ${ }^{2}$ thus, even though the case was concerned with claims for damages, ${ }^{3}$ the court ruled on the possibility to obtain relief, ${ }^{4}$ which is arguably a significantly broader category (Piszcz, 2015, p. 84).

1 CJEU judgment of 20.09.2001, Case C-453/99 Courage and Crehan, ECLI:EU:C:2001:465.

2 Ibid, para. 36. All emphases added by the author.

3 And the CJEU indeed declared in para. 26 that 'The full effectiveness of [Art. 101 TFEU] and, in particular, the practical effect of the prohibition laid down in [Art. 101 (1) TFEU] would be put at risk if it were not open to any individual to claim damages for loss caused to him by a contract or by conduct liable to restrict or distort competition'.

${ }^{4}$ Apart from the right to compensation, the CJEU also specifically discussed the issue of nullity in para. 22: 'That principle of automatic nullity can be relied on by anyone, and the courts are bound by it once the conditions for the application of [Art. 101(1) TFEU] are met and so long as the agreement concerned does not justify the grant of an exemption under 
When the Damages Directive ${ }^{5}$ was finally adopted in 2014, its scope was limited only to compensatory relief of claims stemming from anticompetitive agreements and abuse of dominance in cases capable of significantly affecting trade between EU Member States, ${ }^{6}$ that is, cases with EU dimension. ${ }^{7}$ The aim of the Damages Directive is thus not to stimulate private enforcement as such, but only one part of it - a specific category of damages claims.

While implementing the Damages Directive, Member States are, however, not bound by its limited scope, and they may decide to go beyond it. To assess how did the states of Central and Eastern Europe tackle this issue, we will analyse the legislation adopted (or being adopted) in Bulgaria, Croatia, the Czech Republic, Estonia, Hungary, Latvia, Lithuania, Poland, Romania, Slovakia and Slovenia.

In this article, we first discuss the potential scope of private enforcement of competition law (Chapter II) and contrast it with the actual scope of the Damages Directive (Chapter III). In Chapter IV, we shall analyse the implementing legislation in CEE countries.

In addition, we shall briefly explore the specific topic of the personal scope of the implementation; according to the Damages Directive, the infringer is 'an undertaking or an association of undertakings', ${ }^{8}$ that is, a single economic entity, ${ }^{9}$ potentially composed of several persons where parent companies may be liable for the conduct of their subsidiaries. ${ }^{10}$ In Chapter V, we shall analyse

[Art. 101(3) TFEU] (...) Since the nullity referred to in [Art. 101(2) TFEU] is absolute, an agreement which is null and void by virtue of this provision has no effect as between the contracting parties and cannot be set up against third parties (...) Moreover, it is capable of having a bearing on all the effects, either past or future, of the agreement or decision concerned (...)'.

5 Directive 2014/104/EU of the European Parliament and of the Council of 26.11.2014 on certain rules governing actions for damages under national law for infringements of the competition law provisions of the Member States and of the European Union, OJ L 349, 05.12.2014.

${ }^{6}$ Guidelines on the effect on trade concept contained in Articles 81 and 82 of the Treaty, OJ C 101, 27.04.2004, p. 81.

7 The Damages Directive itself is a part of a broader package of measures intended to foster private enforcement, including the Commission's Communication and Practical Guide on quantifying antitrust harm in damages actions. It is, however, important to notice that this package contains also the Commission's Recommendation on common principles for injunctive and compensatory collective redress mechanisms in the Member States concerning violations of rights granted under Union Law, which addresses not only antitrust claims, but rights stemming from EU law in general, and not only damages claims, but injunctive relief as well; this arguably suggests that the scope of the Damages Directive might also have been wider, as will be discussed below.

8 Damages Directive, Art. 2(2).

9 See e.g. CJEU judgment of 23.04.1991, Case C-41/90 Höfner, ECLI:EU:C:1991:161.

10 See e.g. CJEU judgment of 10.09.2009, Case C-97/08 Akzo Nobel NV, ECLI:EU:C:2009:536. 
to what extent was the concept of a single economic unit implemented into national legislation.

\section{Private enforcement of competition law}

\section{The notion of private enforcement}

Before discussing the scope of the implementation of the Damages Directive, it is first necessary to briefly outline the notion of 'private enforcement' and 'competition law'.

It is not our aim to discuss here in detail the topic of private enforcement, we only want to recall that its scope is much broader than damages claims, which has become the focus of attention following the Commission's activities subsequent to the Courage judgment. ${ }^{11}$ The term is amply summarised by Komninos according to whom, private enforcement is:

'a litigation, in which private parties advance independent civil claims or counterclaims based on the EC competition [law] provision' (Komninos, 2003, p. xxiv).

Private enforcement thus provides different forms of relief to those negatively affected by anticompetitive conduct. Compensatory relief, that is, the right to claim damages, is probably the most common remedy, which will be discussed in the following chapters. The compensation is generally monetary in nature, even though restitution in kind remains a (theoretical) possibility in a few countries (Müller-Graff, 2016, p. 119). In some countries, including the Czech Republic, it is also possible to claim satisfaction in order to compensate immaterial injuries. ${ }^{12}$ Satisfaction has, as a matter of principle,

11 The Commission was clearly aware of this fact, as is evident from its Green Paper Damages Actions for Breach of the EC Antitrust Rules (2005), p. 3: 'Private enforcement in this context means application of antitrust law in civil disputes before national courts. Such application can take different forms. Article 81(2) of the Treaty states that agreements or decisions prohibited by Article 81 are void. The Treaty rules can also be used in actions for injunctive relief. Also, damages awards can be awarded to those who have suffered a loss caused by an infringement of the antitrust rules'. Conversely, it might be argued that the Commission later identified the private enforcement only with the right to compensation, as might be deduced from the Damages Directive, recital 5: 'Actions for damages are only one element of an effective system of private enforcement of infringements of competition law and are complemented by alternative avenues of redress, such as consensual dispute resolution and public enforcement decisions that give parties an incentive to provide compensation'.

12 See e.g. judgment of the Supreme Court of the Czech Republic of 05.05.2006, Ref. No. 32 Odo 511/2006; this judgment was delivered in an unfair competition case, it is however 
a non-pecuniary form, as long as it constitutes a real and sufficiently effective compensation; only in other cases is pecuniary satisfaction admissible. ${ }^{13}$ As a specific form of satisfaction, the publication of the court judgment has been sought in the Czech Republic in the past.

As an independent claim, forfeiture of profits (or restitution of unjust enrichment) may be sought in some countries (Müller-Graff, 2016, p. 119).

Injunctive relief, that is pleas asking the defendant to bring their anticompetitive conduct to an end, is also available in most of the countries, including claims for interim measures (Müller-Graff, 2016, p. 119).

Finally, nullity of contracts is a civil-law consequence of anticompetitive conduct and aggrieved parties may seek declaratory relief, that is ask the court to declare a specific contract (or a part of it) null and void (Müller-Graff, 2016, p. 119); seeking a declaration of nullity will typically be employed in cases based on contractual law (that it is no longer necessary to observe the contract due to its nullity), but may also serve as a basis to claim restitution of unjust enrichment.

In addition, there are also some other remedies which are not specific to private antitrust enforcement, but constitute a general part of civil law of the respective Member States such as, for example, the publication of a judgment, as indicted above, was claimed in several private antitrust enforcement cases in the Czech Republic (Petr and Zorková, 2016, p. II).

Without going into details, it is important to keep in mind that different claims are often 'bundled' in a single court claim; as we have observed in the Czech Republic, the plaintiffs rarely seek only compensatory relief, but they commonly also ask for an injunction or other forms of relief (Petr and Zorková, 2016, p. II).

\section{The notion of competition law}

So far, we have discussed different forms of private enforcement of competition law; the notion of competition law itself is, nonetheless, difficult to define. Indisputably, anticompetitive agreements (Article 101 TFEU) and abuse of a dominant position (Article 102 TFEU), as well as their national-law equivalents, are covered by this term.

applicable to private enforcement of competition law as well. Satisfaction can also be employed to remedy injuries which have material consequences, but cannot be financially quantified, because if they were quantifiable, it would be appropriate to seek damages (judgment of the Supreme Court of the Czech Republic of 14.11.2008, Ref. No. 32 Cdo 1664/2008).

13 Czech Civil Code, Section 2951(2). 
From then on, clear answers are more difficult to find. Regulation 1/2003 itself enables Member States to apply provisions on abusive behaviour toward economically dependent undertakings as part of their competition laws; ${ }^{14}$ therefore, such regulation should presumably be included in the notion of competition law.

Control of concentrations is generally perceived as a part of competition law (Whish and Bailey, 2015, p. 3). If a merger was implemented before being cleared by a competent competition authority, competition law was breached and so it should be possible to rely on private enforcement remedies; the same applies to cases when the merger was cleared on condition the commitments of the merging parties will be fulfilled, but they were in fact breached. We put forward that under such circumstances, injured parties could (and should) be able to rely on the same rules to claim damages as in cartel and antitrust cases, including the limitation periods, quantification of harm etc.

In addition to that, there are other specific rules that pursue similar objectives as competition law, in particular those on state aid, ${ }^{15}$ but also on public procurement. Although these can probably not be properly classified as competition law, the system in which they are regulated is similar. It might thus be argued that also private enforcement in these legal areas should follow the same principles as in the area of competition law, especially if the same competition authorities are responsible for the enforcement of these rules, as is often the case in CEE countries.

Last but not least, there are the rules on unfair competition, which clearly pursue different objectives than rules on agreements and abuses of dominance. However, it may often be the case that an anticompetitive conduct (agreement or abuse of dominance) falls, at the same time, also within the definition of unfair competition. Indeed, in the Czech Republic, a significant proportion of private enforcement claims are based simultaneously on the breach of competition as well as unfair competition law (Petr and Zorková, 2016, p. III). In many EU Member States, competition authorities are also responsible for the enforcement of unfair competition (or consumer protection) legislation. It may thus be argued that for the sake of coherence of civil law, the same rules on private enforcement shall be available for competition as well as unfair competition claims.

14 Regulation $1 / 2003$, recital 8.

15 Private enforcement of state aid law is addressed by the Commission notice on the enforcement of State aid law by national courts, OJ C 85, 09.04.2009, p. 1; this notice is, however, more concerned with the - general - role of national courts in enforcement of state aid law than with specific private enforcement rules. 


\section{The Damages Directive}

As has already been noted above, the Damages Directive only applies to damages claims stemming from anticompetitive agreements and abuse of dominance in cases capable of significantly affecting trade between EU Member States, that is, breaches of Articles 101 and 102 TFEU. In this chapter, we will discuss what this scope actually means, and argue that it might have been significantly broader.

The aim of the Damages Directive is to secure full compensation to anyone harmed by an infringement of competition law. ${ }^{16}$ Clearly, as is also evident from its title, the Damages Directive is only concerned with damages claims, ${ }^{17}$ not private enforcement in its broader meaning. Full compensation shall place a person who has suffered harm in the position in which that person would have been if the infringement of competition law had not been committed. ${ }^{18} \mathrm{It}$ therefore needs to cover 'compensation for actual loss and for loss of profit, plus the payment of interest'. ${ }^{19}$ The Damages Directive thus arguably covers only the monetary compensation of the harm, not restitution or satisfaction; unjust enrichment claims also seem not to be covered by it (Strand, 2014, p. 378 et seq.).

The Damages Directive applies to harm caused by infringements of competition law, which is understood in its narrowest sense as anticompetitive agreements (Article 101 TFEU) and abuse of dominance (Article 102 TFEU). It does not apply to breaches of the law on concentrations. Similarly, distortions of competition by States are not covered, as is the case with other rules which pursue similar objectives to competition law or the application of which is in some Member States entrusted to competition authorities. These include, for example, the rules on state aid, public procurement, unfair competition or the protection of consumers, superior bargaining position etc.

At the same time, the Damages Directive only applies to agreements and abusive conduct capable of affecting trade between Member States, that is, to infringements with 'EU dimension', and falls on corresponding national competition law provisions only inasmuch as it is applied in parallel with the EU one. ${ }^{20}$

The scope of the Damages Directive is thus very limited. Member States have, nonetheless, an opportunity to implement it more broadly, that is,

16 Damages Directive, Art. 1(1).

17 In the Damages Directive, Art. 2(5), 'claim for damages' is defined as 'a claim for compensation for harm caused by an infringement of competition law'.

18 This requirement is in essence the reiteration of the Roman restitutio in integrum.

19 Damages Directive, Art. 3(2).

${ }^{20}$ Damages Directive, Art. 2(3). 
to apply their implementing provisions to other situations than claims for damages for breaches of competition law with EU dimension. Indeed, even though the majority of the provisions of the Damages Directive are applicable only to antitrust damages claims, some may be employed in a more broadly conceived private enforcement.

One of the most novel aspects of the Damages Directive are the rules on disclosure of evidence. ${ }^{21}$ In principle, there is no material reason why such rules should not be applicable to private enforcement in its broader meaning, as described above, or in areas of law other than the strictly defined competition law. Conversely, we put forward that keeping these rules applicable only to strictly defined damages claims may result in serious complications for the more broadly conceived private enforcement. For example, if claimants would come to a court with a claim for damages and for injunctive relief, they might be able to use the evidence gathered by means of the disclosure for the purposes of the damages claim, but not for the injunction. Similarly, if the claim was built on a double legal basis, for example, competition and unfair competition law, the evidence thus collected would arguably be permissible only in the competition law limb of the claim. Without a broader implementation of the Damages Directive, such paradoxes cannot be reconciled. The same applies to other important provisions of the Damages Directive, in particular the binding effect of decisions of national competition authorities. ${ }^{22}$

Similar problems may be caused by the specific rules on limitation periods, ${ }^{23}$ which - among other goals - attempt to reinforce follow-on claims by stating that the limitation period cannot elapse sooner than the infringement decision of a national competition authority becomes final. ${ }^{24}$ It is difficult to argue why there is a legitimate aim in securing compensatory relief thank to specific limitation periods allowing follow-on claims, but at the same time limiting (or indeed precluding) declaratory or injunctive relief based on the same anticompetitive conduct, because the limitation periods for different forms of remedies are construed in an incoherent way.

Even the rules peculiar to damages claims, for example, the rules on the right to full compensation, ${ }^{25}$ the quantification of harm ${ }^{26}$ or the rules on joint and several liability ${ }^{27}$ and the passing-on of overcharges,${ }^{28}$ may be used for

21 Damages Directive, Chapter II.

22 Damages Directive, Art. 9.

23 Damages Directive, Art. 10.

24 Damages Directive, Art. 10(4).

25 Damages Directive, Art. 3.

26 Damages Directive, Art. 17.

27 Damages Directive, Art. 11.

28 Damages Directive, Chapter IV. 
other claims than those based on the narrowly defined concept of competition law; for example, we cannot think of any arguments for calculating the damages for breaches of competition law differently in the case of a breach of Article 102 TFEU than in the case of a breach of superior bargaining position regulation. ${ }^{29}$

Thus, there is a very strong argument for implementing the Damages Directive more broadly than its actual scope suggests.

\section{National legislation}

\section{Introductory remarks}

Even before the implementation of the Damages Directive, private enforcement of competition law was possible in EU Member States (Martinez Lage and Allesandesalazar, 2010, p. 2), either only on the basis of general provisions of tort law, or due to specific provisions applicable only to competition law (Müller-Graff, 2016, p. 118). ${ }^{30}$

The history of private enforcement in the Czech Republic may be illustrative in this regard. When the first modern competition law was enacted in 1991, the competition act contained a specific provision on private enforcement, ${ }^{31}$ enlisting all possible remedies, including injunction, restitution, satisfaction, damages and disgorgement of unjustified enrichment. In 2001, when the current Competition Act was adopted, ${ }^{32}$ it was decided by the legislator that such a provision is no longer necessary, as the claimant may rely directly on general tort law. Interestingly, the Czech Competition Authority attempted to enact certain specific provisions on private enforcement in 2008, but these were rejected by the Government as superfluous (Kreiselová, 2008, p. 4). At present, the new Civil Code, ${ }^{33}$ in force since 2014, provides for specific rules on private enforcement of unfair competition law, ${ }^{34}$ and it adds that the same remedies are available to those who have been aggrieved by breaches

29 In the Czech Republic, that is the Act No. 395/2005 Coll., on superior bargaining position by sale of agricultural products and on its abuse, as amended. Similar regulation is, however, also in place in other CEE countries, including Bulgaria, Hungary Lithuania, Slovakia and Slovenia (Bejček, 2016, p. 281 et seq).

${ }^{30}$ Concerning specifically EU law, the right to claim damages has been guaranteed at least since the Courage judgment of the CJEU.

31 Act No. 63/1991 Coll., on the protection of competition, Sec. 17.

32 Act No. 143/2001 Coll., on the protection of competition, as amended.

33 Act No. 89/2012 Coll., Civil Code, as amended.

34 Czech Civil Code, Sec. 2988. 
of competition law; 35 coincidently, the term 'competition law' is not defined in the Civil Code and there is currently a discussion about what regulation should be covered by these provisions, along the lines outlined in Chapter II.

In several countries, specific rules enhancing private enforcement were adopted even before the Damages Directive, sometimes going beyond its scope. Hungary may serve as an example in this regard; already in 2009, it enacted a rebuttable presumption that cartels increase prices by $10 \%$ (Bodnár, 2017, p. 130).

Despite these 'pre-existing' rules on private enforcement, some level of implementation of the Damages Directive was necessary in all CEE countries. This was done (or is currently in the state of being finalised) mostly by a specific 'self-standing' new act, dedicated exclusively to the implementation of the Damages Directive, ${ }^{36}$ or by amending the respective competition acts. ${ }^{37} \mathrm{In}$ some CEE countries however, the Damages Directive was transposed directly into civil law 'codes', in particular the civil code and the civil procedure code. ${ }^{38}$

We will not discuss 'pre-existing' legislation, but concentrate only on the implementation of the Damages Directive. As this article is concerned specifically with the scope of the implementation, we shall strive to answer the following questions:

(1) does the implementation apply only to conduct with EU dimension?

(2) does the implementation apply only to (strictly defined) competition law?

(3) does the implementation apply only to claims for damages?

\section{The 'EU dimension'}

Due to the principles of subsidiarity and proportionality of EU legislation, the Damages Directive only applies to breaches of EU competition law; since corresponding provisions of national law may nonetheless be applied in parallel with it, ${ }^{39}$ these national provisions are also covered, because otherwise, it would 'adversely affect the position of claimants in the same case'. ${ }^{40}$

35 Czech Civil Code, Sec. 2990.

36 That was the case in Croatia, Czech Republic, Poland and Slovakia.

37 That was the case in Bulgaria, Hungary, Lithuania and Slovenia.

38 That was the case in Estonia, Latvia and Romania.

39 Regulation 1/2003, Art. 3.

40 Damages Directive, recital 10, which stipulates that: 'In the interest of the proper functioning of the internal market and with view to a greater legal certainty and a more level playing field for undertakings and consumers, it is appropriate that the scope of this Directive extend to actions for damages based on infringement of national competition law where it is applied pursuant to Article 3(1) of Regulation (EC) No. 1/2003. Applying differing rules on civil 
Breaches of provisions of purely national competition law, in other words, anticompetitive conduct without EU dimension (in its strict meaning, that is the rules on agreements and abuse of dominance), are not covered by the Damages Directive. The same argument for the inclusion of national law if applied in parallel with EU rules applies, however, also in the case of the application of national law on its own. In our opinion, there is no compelling reason why claims for damages based on the breach of Articles 101 and 102 TFEU should follow different rules than damages claims based on the breach their national equivalents. ${ }^{41}$ This is especially important in countries where most claims are bases only on national law. ${ }^{42}$

This view was shared by all CEE states and so the rules implementing the Damages Directive thus cover also situations in which only national competition law was breached, as is evident from Table $1 .{ }^{43}$

Table 1. Is anticompetitive conduct without EU dimension covered by the implementation?

\begin{tabular}{|c|c|c|c|c|c|c|c|c|c|c|}
\hline BG & HR & CZ & EST & H & LV & LT & PL & RO & SR & SLO \\
\hline YES & YES & YES & YES & YES & YES & YES & YES & YES & YES & YES \\
\hline
\end{tabular}

In addition, the question might also be asked whether domestic implementing provisions also apply, in cases without EU dimension, to breaches of the national competition laws of other countries, on condition the rules of international private law allow such a scenario. This question is usually not discussed by the respective implementing legislations; ${ }^{44} \mathrm{Czech}$ law may thus be unique in stating explicitly that it applies also to breaches of national competition laws of other EU Member States. ${ }^{45}$

\footnotetext{
liability in respect of infringements of Article 101 or 102 TFEU and in respect of infringements of rules of national competition law which must be applied in the same case in parallel to Union competition law would otherwise adversely affect the position of claimants in the same case and the scope of their claims, and would constitute an obstacle to the proper functioning of the internal market'.

41 This issue could not have been addressed by the Damages Directive itself, as it applies only to EU law.

42 E.g., in the Czech Republic over the last 15 years, there was only one private enforcement case where the court directly referred to EU competition law (Petr and Zorková, 2016, p. III).

43 Tables 1 to 3 were prepared by the author of this article, using the information derived from national reports published in Piszcz (ed.), 2017.

${ }^{44}$ E.g., in the Hungarian report, it is only mentioned that this issue is 'ambiguous' (Bodnár, 2017, p. 136).

45 Draft act implementing the Damages Directive, Sec. 1.
} 


\section{The 'competition law'}

The Damages Directive only applies to anticompetitive agreements and the abuse of a dominant position, as defined by Articles 101 and 102 TFEU; other legislation, which may also be called 'competition law', that pursues similar objectives to these Articles or is enforced by the same competition authority, is, however, not covered by the Damages Directive.

Does the implementation of the Damages Directive in CEE states go beyond anticompetitive agreements and abuses? Although pure logic would point to the affirmative, the situation is in fact varied in this regard, with the vast majority of $\mathrm{CEE}$ countries choosing the opposite approach. Thus in eight out of the eleven CEE countries, only agreements and abuses are covered (Croatia, Czech Republic, Estonia, Lithuania, Poland, Romania, Slovakia, Slovenia); broader implementation was adopted only in Bulgaria, Hungary and Latvia, as is evident from Table 2.

Table 2. Does the implementation cover other practices than agreements and abuses?

\begin{tabular}{|c|c|c|c|c|c|c|c|c|c|c|}
\hline BG & HR & CZ & EST & H & LV & LT & PL & RO & SR & SLO \\
\hline YES & NO & NO & NO & YES & YES & NO & NO & NO & NO & NO \\
\hline
\end{tabular}

The methodology used by these countries seems to be the same - extending the implementing provisions to legislation administered by the competition authority. In Hungry, where the implementing provisions were included into the competition act, most of the implementing provisions apply only to Articles 101 and 102 TFEU and their national equivalents, ${ }^{46}$ some of them ${ }^{47}$ also cover the prohibition of unfair manipulation of business decisions ${ }^{48}$ (Bodnár, 2017, p. 135). A similar approach was taken in Bulgaria, ${ }^{49}$ where most of the implementing provisions apply only to Articles 101 and 102 TFEU and their national equivalents, while only the provision on the right to full compensation applies to all the infringements of the Bulgarian Competition Act, including merger control, unfair competition and abuse of superior bargaining position (Petrov, 2017, p. 29). Only in Latvia, where the Damages Directive is to be transposed into numerous legal acts ${ }^{50}$ (in particular the Civil

46 Act LVII of 1996 on the Prohibition of Unfair and Restrictive Market Practices (hereinafter referred to as 'Hungarian Competition Act'), Chapter XIV/A.

47 Hungarian Competition Act, Chapter XIV/B.

48 Hungarian Competition Act, Chapter III.

49 The law was still a draft in August 2017.

50 The law was still a draft in August 2017. 
Procedure Code), the implementing provisions cover breaches of competition law in general, thus including also rules on mergers and unfair competition (Jerneva and Druviete, 2017, p. 159).

\section{The 'private enforcement'}

The situation is even less versatile concerning the different forms of remedies covered by the implementing legislation. In all but one CEE state, the implementation of the Damages Directive only deals with claims for damages; as is evident from Table 3, the only exception is Hungary, where all 'private law remedies' are covered (Bodnár, 2017, p. 134).

Table 3. Does the implementation cover other remedies than damages claims?

\begin{tabular}{|c|c|c|c|c|c|c|c|c|c|c|}
\hline BG & HR & CZ & EST & H & LV & LT & PL & RO & SR & SLO \\
\hline NO & NO & NO & NO & YES & NO & NO & NO & NO & NO & NO \\
\hline
\end{tabular}

In this regard, we should not overlook that in Slovenia, where the legislator intended to implement the Damages Directive in a broader way, covering private enforcement as such (and especially unjustified enrichment claims). The European Commission insisted, however, that the implementation was to be limited only to damages claims, which materialised in the law finally adopted (Vlahek and Podobnik, 2017, p. 271); similar interference has however not been reported in other CEE countries.

\section{The notion of an undertaking}

So far, we have been discussing the material scope of the implementation of the Damages Directive. Concerning its personal scope, the directive is very clear in providing that 'anyone who has suffered harm caused by an infringement of competition law (...) can effectively exercise the right to claim full compensation'; ${ }^{51}$ in that regard, the States have no room to choose the extent of the implementation.

Those harmed may seek redress from infringers, who are to be understood as undertakings (or associations of undertakings) that have committed the infringement; ${ }^{52}$ again, there seems to be no room for manoeuvre for the

51 Damages Directive, Art. 1(1), emphasis added.

52 Damages Directive, Art. 2(2). 
implementation. However, it needs to be observed that civil law generally works with a single legal, as opposed to economic entity. Arguably, it is therefore not self-evident that the civil courts will approach the notion of an undertaking in the same way as competition authorities do..$^{53}$

Such a problem has already materialised in the Czech Republic, where the term 'undertaking' was interpreted in several civil court judgments as a 'competitor', which led to the dismissal of a private enforcement claim (Petr and Zorková, 2016, p. V and VI); this situation has not improved with the implementation of the Damages Directive, as the Czech implementing act does not use the term 'undertaking', but a 'person'. Apparently, the civil caselaw in Bulgaria encountered similar problems with an economic entity broader than the legal one (Petrov, 2017, p. 37).

Some countries, for example Croatia, attempted to overcome this problem by using the term 'undertaking' as defined by competition law, for the purposes of damages claims; it is nonetheless still not clear whether civil courts will follow this concept in full (Malnar, 2017, p. 61). In other CEE countries, for example Hungary (Bodnár, 2017, p. 136) or Lithuania (Mikelénas and Zaščiurinskaité, 2017, p. 192), there are civil-law provisions governing liability of the parent company, even though they cannot arguably cover the complex doctrine of a single economic unit.

Conversely, it seems to be the case that in Slovenia, thanks to the case-law of its courts, the concept of as single economic entity does not cause any problems (Vlahek and Podobnik, 2017, p. 270).

It is thus evident that the usage of the notion of an undertaking as a single economic entity is very diverse in the civil laws of CEE countries; in addition, the civil case-law is, at best, ambiguous, which leads us to the conclusion that this rather overlooked issue deserves more attention in the future.

\section{Conclusions}

The scope of the Damages Directive is quiet narrow, limited to damages claims stemming from anticompetitive agreements and the abuse of dominance in cases capable of significantly affecting trade between EU Member States. This is in line with the general principles of subsidiarity and proportionality, even though arguably, the scope of EU legislation might have been broader,

53 It has been observed that '[m]any Member States, however, do not extend the single economic unit doctrine to private enforcement cases (in which the notion of an "economic unit" (...) may collide with the traditional rules on causality and the responsibility of a legal entity)' (Müller-Graff, 2016, p. 136). 
as is evident from the Commission's initiative in the area of class actions. The decisive element is, nonetheless, that Member States were in the position to implement the Damages Directive more broadly.

We put forward that in order to ascertain effective private enforcement of competition law, the implementation of the Damages Directive should indeed be significantly broader. First, national implementing legislation should cover not only conduct with 'EU dimension', but also breaches of national competition law, without a parallel application of EU law. The coherence of Member States' legal systems would be disrupted if damages claims based on a breach of EU law were directed by one set of rules (the Damages Directive and its implementation), while damages claims based on a materially same conduct, but contrary 'only' to national law, would follow other (purely national) rules. There seems to be a universal agreement on this among the surveyed CEE countries and all of them thus implemented the Damages Directive to cover also the infringements of purely national competition law.

At the same time, we have argued that in order to secure effective private enforcement of competition law, it is not possible to concentrate solely on damages claims, but that other kinds of relief need to be addressed as well. Even though most of the provisions of the Damages Directive are relevant only to damages claims, many may be employed in cases of nullity claims, injunctions etc. We contend that the same argument concerning the coherence of legal systems, outlined above, applies in this case as well. Conversely, to employ different claims stemming from identical material facts, but following different rules, is in our opinion difficult to justify, especially if the claims are 'bundled' in a single legal action. Surprisingly, this opinion was not shared among CEE countries - only in Hungary do the implementing rules cover private enforcement as such.

Finally, we claim that for the sake of the coherence of national legal systems, a broader category of practices distorting competition (than only anticompetitive agreements and the abuse of dominance) ought to be covered by the implementing legislation. Such practices, covered by rules on merger control or superior bargaining position, or in a broader sense unfair competition or state aid, are often prohibited by the same competition act and applied by the same competition authority. From the point of view of a person harmed by distorted competition, it is in our opinion difficult to argue that private enforcement of some of these rules (Articles 101 and 102 TFEU) should be made easier, while others should not. Nonetheless, and rather surprisingly, most of the CEE countries were satisfied with a limited implementation. Only in Bulgaria and Hungary, some aspects of the implementation can be relied upon while enforcing other provisions of their competition acts. Moreover, 
solely in Latvia are all anticompetitive practices enshrined in its competition act covered by the implementing legislation.

We have also observed that the notion of an 'undertaking' as an economic entity might not be easily applicable in civil law cases in many CEE states, potentially endangering the effectiveness of private enforcement, as private and public enforcement might construe their addressees in an incompatible way. Practical experience with this issue has, however, been very limited in CEE countries and their case-law is rather rudimentary; under such circumstances, some more specific guidance, even in the form of legislation, might in our opinion be beneficial for civil courts.

We thus conclude that in order to truly strengthen the legal position of those harmed by anticompetitive conduct, the implementing legislation, even though only recently adopted (or still in the process of adoption) should be revisited and the scope of the implementation of the Damages Directive should be broadened, as suggested above.

\section{Literature}

Bejček, J. (2016). Smluvní svoboda a ochrana slabšiho obchodníka [Contractual Freedom and Protection of a Weaker Undertaking]. Brno: Masarykova univerzita.

Butorac Malnar, V. (2017). Croatia. In: A. Piszcz (ed.), Implementation of the EU Damages Directive in Central and Eastern European Countries. Warsaw: University of Warsaw, Faculty of Management Press.

Komninos, A. (2003). Introduction. In: C. Ehlerman, I. Atanasiu (eds), European Competition Annual 2001: Effective Private Enforcement of EC Antitrust Law. Oxford, Hart Publishing.

Kreiselová, I. (2008). Soukromoprávní vymáhání soutšžního práva opět, ale troche jinak [Private enforcement of competition law again, but in a different way]. Informační list ÚOHS 2, 4-5. Retrieved from: https://www.uohs.cz/download/Informacni_listy/2008/ Infolist_2008_04_Private_enforcement.pdf (12.07.2017).

Jerneva, J. and Druviete, I. (2017). Latvia. In: A. Piszcz (ed.), Implementation of the EU Damages Directive in Central and Eastern European Countries. Warsaw: University of Warsaw, Faculty of Management Press.

Martinez Lage, S. and Allesandesalazar, R. (2010). General Report. In: G.C. Rodriguez Iglesias, L. Ortiz Blanco (eds), The Judicial Application of Competition Law. Proceedings of the FIDE XXIV. Madrid: Universidad Complutense de Madrid.

Mikelénas, V. and Zaščiurinskaité, R. (2017). Lithuania. In: A. Piszcz (ed.), Implementation of the EU Damages Directive in Central and Eastern European Countries. Warsaw: University of Warsaw Faculty of Management Press.

Miskolczi Bodnár, P. (2017). Hungary. In: A. Piszcz (ed.), Implementation of the EU Damages Directive in Central and Eastern European Countries. Warsaw: University of Warsaw, Faculty of Management Press. 
Müller-Graff, P. (2016). General Report. In: G. Bándi, P. Darák, P. Láncos and T. Tóth (eds), Private Enforcement and Collective Redress in European Competition Law. Budapest: Wolters Kluwer.

Petr, M. and Zorková, E. (2016). Soukromé prosazování v České republice [Private Enforcement in the Czech Republic]. Antitrust 2, I-VIII.

Petrov, A. (2017). Bulgaria. In: A. Piszcz (ed.) Implementation of the EU Damages Directive in Central and Eastern European Countries. Warsaw: University of Warsaw Faculty of Management Press.

Piszcz, A. (2015). Piecemeal Harmonisation Through the Damages Directive? Remarks on What Received Too Little Attention in Relation to Private Enforcement of EU Competition Law. Yearbook of Antitrust and Regulatory Studies, 8(12), 79-98.

Piszcz, A. (ed.) (2017). Implementation of the EU Damages Directive in Central and Eastern European Countries. Warsaw: University of Warsaw Faculty of Management Press.

Strand, M. (2014). Indirect Purchasers, Passing-on and the New Directive on Competition Law Damages. European Competition Journal, 2, 361-386.

Vlahek, A. and Podobnik, K. (2017). Slovenia. In: A. Piszcz (ed.), Implementation of the EU Damages Directive in Central and Eastern European Countries. Warsaw: University of Warsaw Faculty of Management Press.

Wish, R. and Bailey, D. (2015). Competition Law. Eighth Edition. Oxford: Oxford University Press. 